\title{
ANALISIS FOREIGN BRANDING, HARGA DAN KUALITAS PRODUK DALAM KEPUTUSAN PEMBELIAN
}

\author{
Sarah Uswatun Hasanah*, Jeni Wulandari, Ghia Subagja \\ Jurusan Ilmu Administrasi Bisnis, Fakultas Ilmu Sosial dan Politik, Universitas Lampung \\ *sarahuswatunhasanah@gmail.com
}

\begin{abstract}
This study examines purchasing decisions of The Executive product, viewed from the aspect of foreig branding, price, and product quality in the perspective of consumer behavior. A quantitative approach was applied, using a questionnaire to 400 respondents. The sampling technique using purposive sampling. Data were analyzed using multiple linear regression analysis. The results of the study indicated that foreign branding, price, and product quality influence purchasing decisions partially and simultaneously had positive and significant effect on purchasing decision. The highest effect in this study was product quality, with comfort and quality of raw material which the main factor need to be maintened because they determined the purchasing decision of The Executive as a fashion product.
\end{abstract}

Keywords: foreign branding, price, product quality, and purchasing decision

\begin{abstract}
ABSTRAK
Studi ini mengkaji keputusan pembelian produk The Executive, dilihat dari aspek foreign branding, harga, dan kualitas produk dalam perspektif perilaku konsumen. Pendekatan kuantitatif diterapkan, dengan menggunakan kuesioner pada 400 responden. Teknik pengambilan sampel menggunakan purposive sampling. Data dianalisis menggunakan analisis deskriptif dan regresi linear berganda. Hasil studi menunjukkan bahwa secara parsial dan simultan, foreign branding, harga, dan kualitas produk berpengaruh terhadap keputusan pembelian. Pengaruh terbesar terletak pada variabel kualitas produk, dengan kenyamanan dan kualitas bahan baku menjadi faktor dominan yang perlu dipertahankan, karena menentukan keputusan pembelian The Executive sebagai produk fashion.
\end{abstract}

Kata kunci: foreign branding, harga, kualitas produk, dan keputusan pembelian

\section{PENDAHULUAN}

Perkembangan bisnis yang begitu pesat, menjadikan semakin banyak dan beragamnya produk yang ditawarkan oleh perusahaan pada industri yang sama. Kondisi 
ini membuat persaingan industri di Indonesia semakin ketat. Untuk dapat mengatasi persaingan, guna memenuhi kebutuhan dan keinginan konsumen, para pebisnis terus mengembangkan ide-ide kreatif dalam bisnisnya, yang kemudian ide kreatif itu memunculkan suatu industri baru yang lebih dikenal dengan sebutan industri kreatif.

Menurut Kemenprekraf RI (2014) dalam Sugiono et al., (2017), industri kreatif merupakan subsistem dari ekonomi kreatif yang terdiri dari core creative industry, forward and backward linkage creative industry. Core creative industry adalah industri kreatif yang penciptaan nilai tambah utamanya adalah pemanfaatan kreativitas orang kreatif, forward linkage adalah kegiatan dimana pelaku usaha di subsektor tersebut mampu mendorong sektor lain supaya lebih berkembang. Sedangkan backward linkage adalah kegiatan pelaku industri kreatif di sub sektor unggulan yang membutuhkan sektor lain, untuk kelancaran aktivitas bisnisnya.

Berdasarkan data dari Badan Ekonomi Kreatif (Bekraf) tahun 2016, dijelaskan bahwa sektor ekonomi kreatif menyumbang 7,38\% terhadap total perekonomian nasional (Margaretta, 2017). Terdapat tiga subsektor industri yang berkontribusi terhadap perekonomian Indonesia, yaitu kuliner berkontribusi (41,69\%), fashion (18,15\%), dan kriya $(15,70 \%)$. Meskipun industri kuliner menduduki posisi pertama, pertumbuhan industri fashion yang bukan termasuk kebutuhan primer masih sangat berpotensi di tahun ini. Pertumbuhan industri fashion di Indonesia, salah satunya ditandai dengan semakin banyak retail produk fashion lokal yang terdapat diberbagai mall Indonesia yang menjual pakaian ready to wear.

Persaingan pada industri fashion yang mengusung konsep ready to wear terjadi antara sesama pelaku bisnis lokal, karena hanya dengan bahan yang tidak terlalu mahal, namun dengan konsep dan branding yang matang, serta marketing yang tepat, maka harganya pun bisa dijual dengan sangat mahal (Haris, 2018). Banyaknya produk pakaian ready to wear yang ditawarkan menjadikan semakin beragam merek-merek yang beredar di pasaran. Sehingga kemajemukan itu membuat konsumen terkadang sulit membedakan produk asli Indonesia dengan produk impor, dikarenakan salah satu strategi yang digunakan adalah pemberian nama merek dengan berbahasa asing. Penggunaan foreign branding disebabkan karena selain mempermudah penetrasinya ke pasar internasional, dapat meningkatkan nilai dari produk dengan mengekploitasi stereotip konsumen tentang negara yang dicitrakan (Diantanti, et al., 2018).

Salah satu merek fashion Indonesia yang berhasil menggunakan strategi foreign branding adalah The Executive. Merek yang dulu bernama Executive 99 ini merupakan bagian dari grup Delamibrands yang menyediakan berbagai pakaian resmi pria dan wanita seperti blazer, shirt, blouse, pants, dress hingga apparel pendukungnya. Keberhasilan The executive tergambar dari diperolehnya penghargaan Top Brand Award tahun 2018-2020 selama tiga tahun berturut-turut, dengan mengalahkan beberapa merek fashion impor ternama untuk kategori pakaian kerja wanita, jaz, dan blazer (topbrand-award.com, 2020). Saat ini, ditandai dengan jaringan penjualannya yang luas, The Executive sudah memiliki 60 toko dan lebih dari 100 gerai yang dapat ditemui dibeberapa pusat perbelanjaan kota di Indonesia (theexecutive.co.id, 2020), brand yang dibangun juga dinilai baik oleh masyarakat, terbukti selama tiga tahun berturut-turut The Executive mampu memimpin pasar. Hal tersebut juga dapat dikarenakan dari segi harga dan kualitas, produk The Executive tidak kalah dengan produk internasional. Dengan harga yang terjangkau berkisar 
antara Rp. 200.000 - Rp. 400.000 konsumen sudah bisa mendapatkan produk dengan kualitas yang sebanding dengan brand ternama.

Berdasarkan kajian perilaku konsumen, ketiga variabel tersebut, baik foreign branding, harga, dan kualitas produk, dapat dijelaskan melalui model perilaku konsumen (Kotler \& Keller, 2016:187). Kesan merek yang berasal dari luar, didukung dengan strategi penetapan harga dan kualitas yang baik, ketiganya merupakan faktor dari rangsangan pemasaran yang digunakan The Executive untuk mempengaruhi keputusan pembelian. Fenomena tersebut menarik untuk diteliti, karena sebagai merek fashion lokal, The Executive dapat dikatakan bahwa produkya mampu bersaing dengan produk internasional. Foreign branding, harga, dan kualitas produk dapat menjadi faktor yang mempengaruhi keputusan pembelian konsumen The Executive, sebagaimana terdapat dalam beberapa penelitian terdahulu yang menjelaskan keterkaitan ketiga variabel tersebut terhadap keputusan pembelian (Aichner et al., 2016; Fatmawati \& Suryoko, 2018; Mandasari et al., 2015).

Menurut Leclerc et al., dalam Villar et al., (2012), menyatakan bahwa foreign branding adalah strategi branding dengan pemberian nama merek menggunakan pengejaan atau pengucapan dalam bahasa asing tertentu, dengan target utama mempengaruhi dimensi citra merek, dan mempengaruhi persepsi kualitas, serta sikap konsumen terhadap produk. Indikator foreign branding meliputi: kemewahan merek, prestise merek, nama dan pelafalan merek, kesesuaian arti nama merek, kualitas merek, asosiasi merek (Ariesmendi et al., 2016). Terdapat penelitian sebelumnya yang menunjukkan variabel foreign branding memiliki pengaruh dengan keputusan pembelian, sebagaimana penelitian yang telah dilakukan oleh Aichner et al., (2016). Berdasarkan hasil penelitian tersebut, maka dapat disusun hipotesis pertama, yaitu:

H1: Foreign branding berpengaruh signifikan terhadap keputusan pembelian produk The Executive.

Harga adalah jumlah yang dibebankan untuk suatu produk atau layanan (Kotler \& Armstrog, 2016:324). Indikator harga dalam penelitian ini meliputi, keterjangkauan harga, kesesuaian harga dengan kualitas produk, daya saing harga, dan kesesuaian harga dengan manfaat (Tjiptono, 2015:156). Terdapat beberapa penelitian terdahulu yang menunjukkan pengaruh harga dengan keputusan pembelian, sebagaimana penelitian yang telah dilakukan oleh Fatmawati \& Suryoko (2016), bahwa harga berpengaruh positif terhadap keputusan pembelian. Berdasarkan hasil penelitian tersebut, maka dapat disusun hipotesis kedua, yaitu:

H2: Harga berpengaruh signifikan terhadap keputusan pembelian produk The Executive.

Menurut American Society dalam Kotler \& Keller (2016:156), kualitas adalah totalitas fitur dan karakteristik produk atau jasa yang bergantung pada kemampuannya untuk memuaskan kebutuhan yang dinyatakan atau tersirat. Indikator yang digunakan untuk mengukur variabel kualitas produk, yakni kinerja (performance), fitur (features), reliabilitas, konformasi (conformance), daya tahan (durability), serviceability, estetika (aesthetic), persepsi terhadap kualitas (Tjiptono \& Chandra, 2017:88). Terdapat beberapa penelitian terdahulu yang menunjukkan pengaruh kualitas produk dengan keputusan pembelian, sebagaimana penelitian yang telah dilakukan oleh Mandasari et al., (2015), bahwa kualitas produk berpengaruh positif terhadap keputusan pembelian. Berdasarkan hasil penelitian tersebut, maka dapat disusun hipotesis ketiga, yaitu: 
H3: Kualitas produk berpengaruh signifikan terhadap keputusan pembelian produk The Executive.

Keputusan pembelian yang dilakukan konsumen terhadap suatu produk tidak terjadi dengan begitu saja. Sebelum mencapai keputusan pembelian, konsumen melewati berbagai proses keputusan-keputusan yang diambil dan dipertimbangkan dari berbagai faktor, sehingga membentuk struktur keputusan pembelian. Menurut Kotler \& Keller (2016:195), keputusan pembelian merupakan proses dimana konsumen melewati lima tahap, yaitu pengenalan masalah, pencarian informasi, evaluasi alternatif, keputusan pembelian, dan perilaku pasca pembelian, yang dimulai jauh sebelum pembelian aktual dilakukan dan memiliki dampak yang lama setelah itu. Hal ini berarti terdapat banyak faktor yang dapat mempengaruhi keputusan konsumen dalam melakukan pembelian, seperti ketiga variabel pada penelitian ini yaitu, foreign branding, harga, dan kualitas produk yang memiliki keterkaitan secara simultan terhadap keputusan pembelian produk The Executive (Aichner et al., 2016; Mandasari et al., 2015; Fatmawati \& Suryoko, 2016). Berdasarkan hal tersebut maka dapat disusun hipotesis keempat, yaitu:

H4: Foreign branding, harga, dan kualitas produk secara simultan berpengaruh signifikan terhadap keputusan pembelian produk The Executive.

\section{METODE PENELITIAN}

Penelitian ini merupakan jenis penelitian explanatory research dengan pendekatan kuantitatif. Populasi dalam penelitian ini adalah followers akun instagram @id_theexecutive berjumlah 179.000 pada periode bulan Juli 2020. Sampel dalam penelitian ini sebanyak 400 responden, yang didapat dengan menggunakan rumus Yamane dengan tingkat toleransi kesalahan (margin of eror) sebesar $5 \%$. Penarikan sampel dalam penelitian ini menggunakan nonprobability sampling dengan teknik sampling yang digunakan yaitu purposive sampling, teknik pengambilan sampel dengan didasarkan ciri-ciri khusus yang sesuai dengan tujuan penelitian sehingga diharapkan dapat menjawab permasalahan penelitian (Sugiyono, 2017). Penyebaran kuesioner penelitian ini dilakukan secara online menggunakan google form melalui media sosial instagram.

Adapun analisis data dilakukan dalam beberapa tahapan, yakni analisis deskriptif yang meliputi karakteristik responden dan distribusi jawaban responden, lalu uji asumsi klasik (normalitas, heteroskedastisitas, dan multikolinieritas), analisis regresi linear berganda, uji t, uji f, koefisien determinasi.

\section{HASIL PENELITIAN}

Dalam penelitian ini analisis data menggunakan SPSS versi 25.0 for windows. Metode yang digunakan dalam penelitian sebagai berikut :

Analisis Statistik Deskriptif 
Berdasarkan hasil analisis deskriptif, dapat diketahui dari 400 responden dalam penelitian ini tidak memiliki perbedaan yang cukup jauh antara responden perempuan (59\%) dan laki-laki (41\%), dengan rentang usia terbesar 21-27 tahun (64\%). Berdasarkan provinsi didominasi oleh Jawa Barat dengan persentase 18,5\% atau terdiri dari 74 orang, lalu berdasarkan pekerjaan, tidak memiliki perbedaan yang cukup jauh antara karyawan swasta dan kalangan pelajar/mahasiwa yakni dengan persentase (41\%) dan (38\%), dengan pendapatan, rata-rata terbanyak dalam rentang Rp 2.500.001 - Rp 5.000.000 per-bulan dengan presentase $28 \%$.

Berdasarkan jumlah pembelian produk, responden telah melakukan pembelian sebanyak lebih dari dua kali sebesar (76\%) dengan kategori pembelian produk yaitu, shirts (146 orang), pants (145 orang), dan t-shirts (121 orang). Kemudian sebanyak $79 \%$ responden sudah mengatahui bahwa The Executive merupakan produk lokal, dan sisanya sebanyak $21 \%$ masih belum mengetahui.

\section{Distribusi Jawaban Responden}

Foreign branding menjadi salah satu variabel penting yang mempengaruhi keputusan pembelian The Executive. Nilai interpretasi skala jawaban responden terhadap variabel foreign branding (X1), memiliki nilai rata-rata sebesar 4.41 meliputi nama dan pelafalan merek mudah dilafalkan, kesesuaian arti nama merek, kualitas merek yang baik, asosiasi merek sebagai high-quality brand. Sedangkan item yang berada dibawah rata-rata, meliputi kemewahan merek, prestise merek, nama dan pelafalan merek terdengar unik, kualitas merek memberikan kesan menarik, dan asosiasi merek berasal dari luar negeri.

Sedangkan pada variabel harga $(\mathrm{X} 2)$ memiliki nilai interpretasi nilai rata-rata tertinggi sebesar 4.25 meliputi kesesuaian harga dengan kualitas produk, daya saing harga, kesesuaian harga dengan manfaat tidak merasakan dirugikan, dan kesesuaian harga dengan manfaat style. Sedangkan item yang dibawah rata-rata yaitu keterjangkauan harga sebesar 4.00, dan untuk variabel kualitas produk (X3), nilai interpretasi di atas rata-rata sebesar 4.33 meliputi fitur, reliabilitas mengenai kepuasan dan kenyamanan, konformasi, daya tahan produk, serviceability, dan persepsi terhadap kualitas. Sedangkan item yang berada dibawah rata-rata meliputi kinerja (performance), reliabilitas mengenai kelebihan produk, daya tahan (durability) mengenai biaya perbaikan, dan estetika (aesthetics).

Pada variabel keputusan pembelian $(Y)$ nilai yang berada di atas rata-rata sebesar 4.30 meliputi pencarian informasi dengan mengunjungi outletnya langsung, evaluasi alternatif membandingkan dengan produk luar, evaluasi alternatif dengan membandingkan desain produk, keyakinan melakukan keputusan pembelian, perilaku pasca pembelian. Sedangkan item yang berada di bawah rata-rata meliputi pengenalan masalah, pencarian informasi melalui media sosial, evaluasi alternatif dengan mencari informasi tentang produk sejenis di toko lain, evaluasi alternatif dengan membandingkan harga, keputusan pembelian setelah membandingkan produk.

\section{Uji Asumsi Klasik}

Uji asumsi klasik dalam penelitian ini bertujuan untuk menguji data-data yang digunakan dalam penelitian ini, apakah telah memenuhi asumsi klasik, yaitu data 
terdistribusi normal, tidak terjadi multikolinearitas, dan tidak terjadi gejala heteroskedastitas.

\section{Uji Normalitas}

Untuk melakukan uji normalitas, akan digunakan alat uji yakni normal P-P Plot of Regression Standardized Residual. Pendekatan P-Plot dilakukan dengan mengamati titik-titik penyebaran data pada diagram. Sebuah data dapat dikatakan memenuhi asumsi normalitas apabila sebaran titik-titik data terlihat menyebar di sekitar garis diagonal dan mengikuti arah garis. Hal tersebut juga berlaku sebaliknya, apabila titik-titik tersebar menjauhi garis diagonal atau tidak mengikuti arah garis maka data tersebut tidak memenuhi asumsi normalitas (Ghozali, 2011:160). Berikut ini merupakan hasil uji normalitas pada penelitian ini:

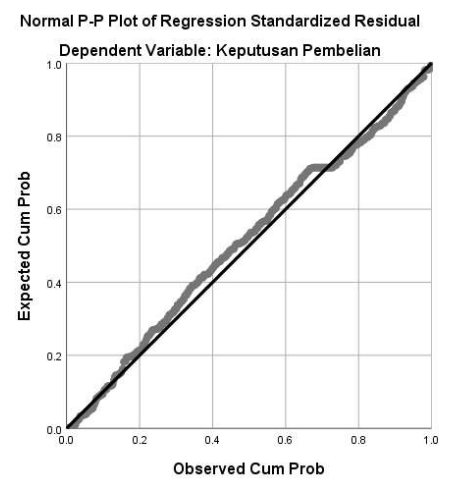

Gambar 1. Hasil Uji Normalitas

Berdasarkan Normal P-Plot Regression Standarized Residual pada Gambar 1 diketahui bahwa dalam penelitian ini, menunjukkan variabel yang diuji berdistribusi normal, karena garis titik-titik mengikuti garis diagonal. Hal ini juga menunjukkan bahwa penyebaran kuesioner penelitian ini telah terdistribusi normal dan mewakili beberapa pihak (subpopulasi). Dengan demikian, residual dalam penelitian ini telah memenuhi asumsi normalitas.

\section{Uji Heteroskedastisitas}

Uji heterokedastisitas digunakan untuk melihat apakah terdapat ketidaksamaan varian dari residual satu ke pengamatan yang lain. Jika varian tetap, maka terjadi masalah hetrokedastisitas yaitu melihat scatter plot (nilai prediksi dependen ZPRED dengan residual SRESID).

Berdasarkan gambar 2 terlihat bahwa pola pada penyebaran data berupa titik-titik pada scatterplot tidak membentuk suatu pola atur alur tertentu, sehinga dapat disimpulkan bahwa tidak terjadi heteroskedastisitas (Priyatno, 2010:67). Dengan demikian uji klasik heteroskedastisitas dalam model ini terpenuhi. Uji ini dilakukan untuk mengetahui adanya penyimpangan dari syarat-syarat asumsi klasik pada regresi linear berganda dimana dalam model regresi harus dipenuhi syarat tidak adanya heteroskedastisitas. 


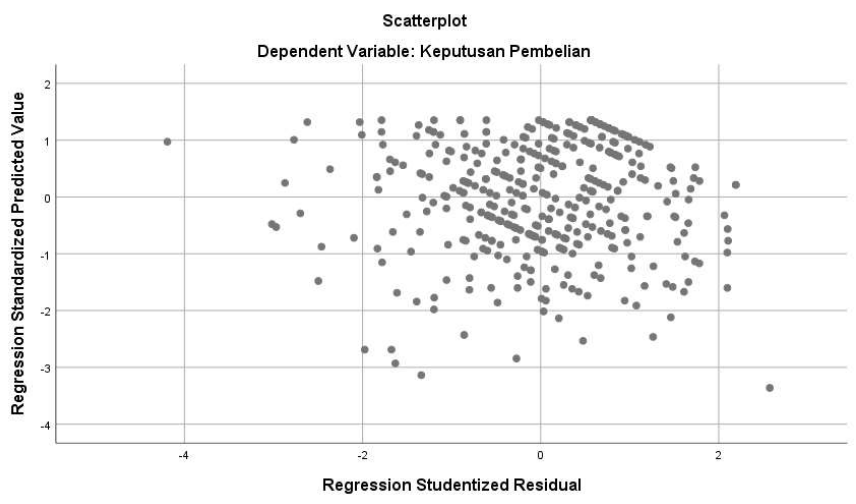

Gambar 2. Hasil Uji Heteroskedastisitas

\section{Uji Multikolinieritas}

Uji multikolinieritas digunakan untuk menguji apakah model regresi ditemukan ada tidaknya korelasi antar variabel (variabel independen). Hal tersebut dikarenakan jika terdapat korelasi yang tinggi antar variabel independen maka dapat mengganggu hubungan antara variabel independen dan variabel dependennya. Untuk melihat apakah ada multikolinieritas, maka akan dilihat dari nilai Variance Inflation Factor (VIF) dan Tolerance. Jika Tolerance lebih besar dari 0,10 dan nilai VIF kurang dari 10, maka variabel tersebut tidak mempunyai persoalan multikolinieritas dengan variabel bebas lainnya (Ghozali, 2011:105). Berikut ini merupakan hasil uji multikolinieritas dalam penelitian ini:

Tabel 1. Hasil Uji Multikolinieritas

\begin{tabular}{|l|l|l|}
\hline Variabel & Tolerance & VIF \\
\hline ForeignBranding & 0,389 & 2.572 \\
\hline Harga & 0,477 & 2.240 \\
\hline Kualitas Produk & 0,308 & 3.242 \\
\hline
\end{tabular}

Pada tabel 1 menunjukan bahwa keseluruhan variabel bebas memiliki nilai Variances Inflanction Factor (VIF) $<10$ dan nilai tolerance $>0,10$. Maka dapat disimpulkan dalam penelitian ini tidak terjadi multikolinieritas yang berarti tidak terdapat korelasi antar variabel bebas atau variabel independen sehingga tidak mengganggu hubungan antar varaibel bebas dan terikat.

\section{Analisis Regresi Linear Berganda}

Analisis regresi berganda digunakan dalam penelitian ini dengan tujuan untuk membuktikan hipotesis mengenai adanya pengaruh variabel independen atau lebih secara bersama-sama dengan suatu variabel dependen. Hasil dari analisis regresi linear berganda dapat dilihat pada tabel 2 berikut: 
Tabel 2. Hasil Perhitungan Regresi Linear Berganda

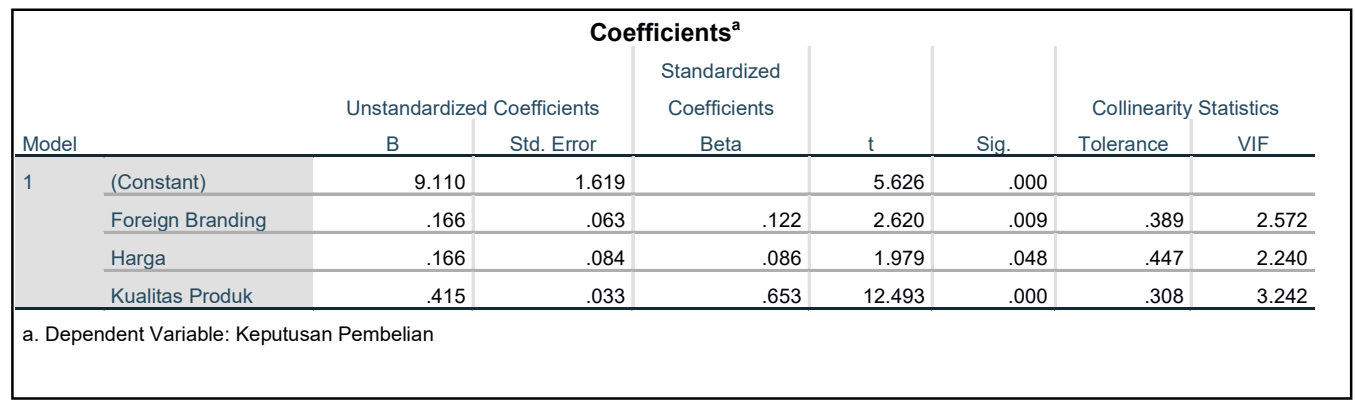

Hasil perhitungan regresi linear berganda, dapat dilihat bahwa nilai konstanta sebesar 9,110, nilai foreign branding (X1) sebesar 0.166, harga (X2) sebesar 0.166, dan kualitas produk (X3) sebesar 0.415. Berdasarkan nilai-nilai tersebut pada masing-masing variabel, maka untuk mengetahui pengaruh foreign branding, harga, dan kualitas produk terhadap keputusan pembelian produk The Executive dapat dilihat pada persamaan regresi berikut ini:

$$
\begin{gathered}
Y=\alpha+\beta_{1} X 1+\beta_{2} X 2+\beta_{3} X 3+e \\
Y=9,110+0.166+0.166+0.415+e
\end{gathered}
$$

Persamaan regresi dalam penelitian ini memiliki konstanta sebesar 9,110 yang berarti bahwa jika variabel independen foreign branding (X1), harga (X2), kualitas produk (X3) memiliki nilai 0, maka nilai variabel dependen keputusan pembelian (Y) adalah sebesar 9,110. Koefisien regresi linear berganda variabel foreign branding (X1) bernilai positif sebesar 0,166 . Hal ini menunjukkan bahwa terjadi pengaruh yang positif antara variabel foreign branding $(\mathrm{X} 1)$ terhadap keputusan pembelian $(\mathrm{Y})$. Artinya setiap terjadi kenaikan nilai 1 dari variabel foreign branding, maka keputusan pembelian produk The Executive akan mengalami peningkatan sebesar 0,166.

Koefisien regresi linear berganda variabel harga (X2) bernilai positif sebesar 0,166. Hal ini menunjukkan bahwa terjadi pengaruh yang positif antara variabel harga (X2) terhadap keputusan pembelian (Y). Artinya setiap terjadi kenaikan nilai 1 dari variabel harga, maka keputusan pembelian produk The Executive akan mengalami peningkatan sebesar 0,166. Koefisien regresi linear berganda variabel kualitas produk (X3) bernilai positif sebesar 0,415. Hal ini menunjukkan bahwa terjadi pengaruh yang positif antara variabel kualitas produk (X3) terhadap keputusan pembelian (Y). Artinya setiap terjadi kenaikan nilai 1 dari variabel kualitas produk, maka keputusan pembelian produk The Executive akan mengalami peningkatan sebesar 0,415.

\section{Uji Hipotesis}

Pengujian hipotesis dalam penelitian ini menggunakan pengujian secara parsial yang terdiri dari uji $\mathrm{t}$, pengujian secara simultan yakni dengan uji $\mathrm{F}$.

Tabel 3. Hasil Uji T

\begin{tabular}{|l|l|l|l|l|}
\hline Variabel & $\mathbf{t}_{\text {hitung }}$ & $\mathbf{t}_{\text {tabel }}$ & Sig & Keterangan \\
\hline $\begin{array}{l}\text { Foreign Branding } \\
(\mathrm{X} 1 \rightarrow \mathrm{Y})\end{array}$ & 2,620 & 1,966 & 0,009 & Ha diterima, Ho ditolak \\
\hline
\end{tabular}




\begin{tabular}{|l|l|c|c|c|}
\hline $\begin{array}{l}\text { Harga } \\
(\mathrm{X} 2 \rightarrow \mathrm{Y})\end{array}$ & 1,979 & 1,966 & 0,048 & Ha diterima, Ho ditolak \\
\hline $\begin{array}{l}\text { Kualitas Produk } \\
(\mathrm{X} 3 \rightarrow \mathrm{Y})\end{array}$ & 12,493 & 1,966 & 0,000 & Ha diterima, Ho ditolak \\
\hline
\end{tabular}

Berdasarkan tabel 3 dapat dilihat bahwa hasil uji X1 terhadap $\mathrm{Y}$ pada variabel foreign branding (X1) memiliki nilai t-hitung sebesar 2,620 dan t-tabel sebesar 1,966, yang berarti thitung $>$ t-tabel. Variabel foreign branding memiliki nilai signifikansi sebesar 0,009 atau memiliki nilai $<0,05$. Hal tersebut dapat diartikan bahwa secara parsial suasana toko berpengaruh signifikan terhadap keputusan pembelian produk The Executive. Maka dapat disimpulkan bahwa H1 diterima. Adapun besar pengaruh variabel X1 terhadap Y adalah sebesar 12,2\% (Lihat tabel 2).

Hasil uji X2 terhadap Y pada variabel harga (X2) memiliki nilai t-hitung sebesar 1,979 dan t-tabel sebesar 1,966 yang berarti t-hitung $>$ t-tabel. Kemudian, variabel harga memiliki nilai signifikansi sebesar 0,048 atau memiliki nilai < 0,05. Hal tersebut dapat diartikan bahwa secara parsial harga berpengaruh signifikan terhadap keputusan pembelian produk The Executive. Maka dapat disimpulkan bahwa H2 diterima. Adapun besar pengaruh variabel $\mathrm{X} 2$ terhadap $\mathrm{Y}$ adalah sebesar 8,6\% (Lihat tabel 2).

Hasil uji X3 terhadap Y pada variabel kualitas produk (X3) memiliki nilai t-hitung sebesar 12,493 dan t-tabel sebesar 1,966 yang berarti t-hitung $>\mathrm{t}$-tabel. Variabel kualitas produk memiliki nilai signifikansi sebesar 0,000 atau memiliki nilai $<0,05$. Hal tersebut dapat diartikan bahwa secara parsial kualitas produk berpengaruh signifikan terhadap keputusan pembelian produk The Executive. Maka dapat disimpulkan bahwa H3 diterima. Adapun besar pengaruh variabel X3 terhadap Y adalah sebesar 65,3\% (Lihat tabel 2).

Tabel 4. Hasil Uji F

\begin{tabular}{|c|l|c|c|l|}
\hline Variabel & $\mathbf{F}_{\text {hitung }}$ & $\mathbf{F}_{\text {tabel }}$ & Sig & Keterangan \\
\hline$(\mathrm{X} 1, \mathrm{X} 2$, dan $\mathrm{X} 3 \rightarrow \mathrm{Y})$ & 264,105 & 2,24 & 0,000 & Ha diterima, Ho ditolak \\
\hline
\end{tabular}

Pada tabel 4 diperoleh f-hitung sebesar 264,105 dengan tingkat signifikan 0,000. Sedangkan nilai f-tabel pada penelitian ini adalah sebesar 2,24. Berdasarkan hal tersebut dapat diketahui bahwa nilai f-hitung $>$ f-tabel atau 264,105 dengan $>2,24$. Hal tersebut berarti bahwa Ha diterima dan Ho ditolak, yang berarti terdapat pengaruh secara simultan antara variabel foreign branding, harga, dan kualitas produk terhadap keputusan pembelian. Oleh karena itu dalam penelitian ini dapat disimpulkan bahwa H4 diterima.

\section{Koefisien Determinasi}

Koefisien determinasi $\left(\mathrm{R}^{2}\right)$ digunakan untuk mengukur seberapa jauh kemampuan model independen dalam menerangkan variasi variabel dependen. Nilai koefisien determinasi adalah antara 0 dan 1 . Model yang baik adalah yang mempunyai nilai yang tinggi atau mendekati angka 1 (Ghozali, 2011:98). Berikut ini merupakan hasil dari uji $\mathrm{R}^{2}$ dalam penelitian ini:

Table 5. Hasil Uji R² 


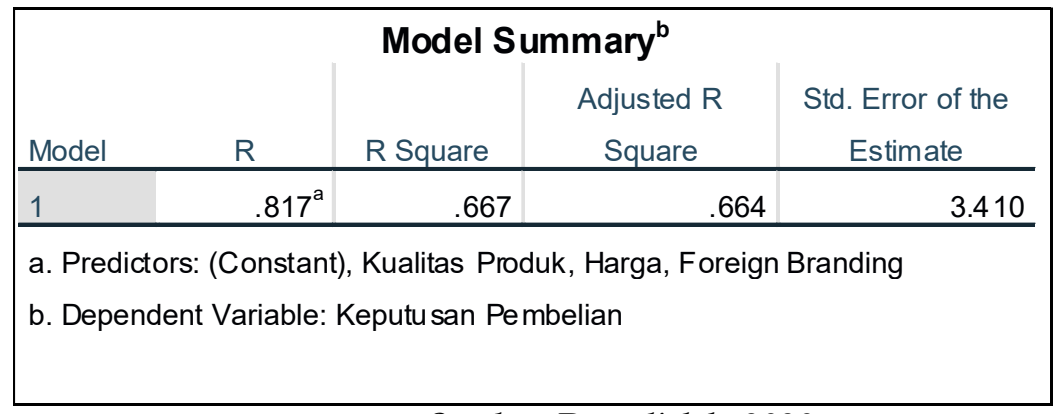

Sumber: Data diolah, 2020.

Dapat dilihat bahwa dalam penelitian ini diperoleh nilai koefisien determinasi $\left(\mathrm{R}^{2}\right)$ yang ditunjukan oleh R-square sebesar 0,667. Angka tersebut menunjukan besar pengaruh variabel independen yang terdiri dari foreign branding, harga, dan kualitas produk sebesar 0,667 atau $66,7 \%$. Hal tersebut dapat diartikan bahwa sebesar $66,7 \%$ variasi keputusan pembelian dipengaruhi oleh ketiga variabel independen dalam penelitian ini, yakni foreign branding, harga, dan kualitas produk, serta sisanya sebesar 33,3\% dapat dikatakan dipengaruhi oleh variabel-variabel lain yang tidak diteliti dalam penelitian ini.

\section{PEMBAHASAN}

\section{Pengaruh Foreign Branding terhadap Keputusan Pembelian}

Hasil penelitian mengenai pengaruh foreign branding terhadap keputusan pembelian menunjukkan bahwa koefisien regresi linear berganda variabel foreign branding (X1) sebesar 0.166. Berarti setiap terjadi kenaikan nilai 1 dari variabel foreign branding, maka keputusan pembelian akan mengalami peningkatan sebesar 0.166, dengan asumsi variabel yang lainnya dianggap konstan atau tetap. Koefisien regresi bernilai positif artinya terjadi pengaruh yang positif antara variabel foreign branding terhadap keputusan pembelian produk The Executive. Semakin naik nilai variabel foreign branding, maka akan semakin meningkatkan keputusan pembelian. Sementara itu, hasil pengujian hipotesis menunjukkan bahwa terdapat pengaruh yang signifikan foreign branding terhadap keputusan pembelian. Adapun besar pengaruh foreign branding terhadap keputusan pembelian adalah $12,2 \%$.

Hasil penelitian ini sejalan dengan penelitian yang pernah dilakukan Aichner, et al., (2016), yang menemukan adanya pengaruh positif dan signifikan foreign branding terhadap kesediaan konsumen untuk membeli dan membayar. Diperkuat dengan penelitian Ergin, et al., (2014) bahwa produk dengan foreign branding lebih menimbulkan sikap dan persepsi konsumen yang positif dibanding merek nasional. Beberapa alasan konsumen lebih memilih foreign branding dikarenakan keyakinan pada kualitas, keandalan, fungsionalitas, dan prestise. Dengan menggunakan strategi foreign branding, maka akan menguntungkan pihak perusahaan dan konsumen. Penggunaan foreign branding merupakan salah satu faktor keberhasilan The Executive dalam memasarkan produknya, dikarenakan foreign branding mampu meningkatkan citra merek dan kualitas dari produk.

Pengaruh Harga terhadap Keputusan Pembelian 
Strategi penetapan harga yang dilakukan The Executive juga membuat keputusan pembelian konsumen menjadi meningkat, karena konsumen percaya bahwa harga produk The Executive mampu bersaing dengan produk lain yang sejenis. Hasil penelitian mengenai pengaruh harga terhadap terhadap keputusan pembelian menunjukkan bahwa koefisien regresi linear berganda variabel harga sebesar 0.166 . Berarti setiap terjadi kenaikan nilai 1 dari variabel harga, maka keputusan pembelian akan mengalami kenaikan sebesar 0.166, dengan asumsi variabel yang lainnya dianggap konstan atautetap. Koefisien regresi bernilai positif $(+)$, artinya terjadi pengaruh yang positif antara variabel harga terhadap keputusan pembelian produk The Executive. Semakin naik nilai variabel harga, maka akan semakin meningkatkan keputusan pembelian. Adapun besar pengaruh harga terhadap keputusan pembelian adalah $8,6 \%$.

Hasil penelitian ini sejalan dengan penelitian Asshiddieqi \& Mudiantono (2012), bahwa semakin baik penerimaan konsumen mengenai harga, maka semakin besar keputusan pembelian yang diberikan konsumen. Calon konsumen akan mempertimbangkan seberapa besar uang yang akan dikeluarkan dengan kebutuhan dan kepuasan yang dirasakan atas suatu produk yang akan dibeli. Dengan penentuan harga yang tepat sejalan dengan kualitas yang diberikan, menjadikan The Executive mampu bersaing di pasar.

Pengaruh Ukuran Perusahaan terhadap Corporate Social Responsibility Disclosure.

Hasil penelitian mengenai pengaruh kualitas produk terhadap keputusan pembelian menunjukkan bahwa koefisien regresi linear berganda variabel kualitas produk (X3) sebesar 0.415. Berarti setiap terjadi kenaikan nilai 1 dari variabel kualitas produk, maka keputusan pembelian akan mengalami peningkatan sebesar 0.415 , dengan asumsi variabel yang lainnya dianggap konstan atau tetap. Koefisien regresi bernilai positif artinya terjadi pengaruh yang positif antara variabel kualitas produk terhadap keputusan pembelian produk The Executive. Semakin naik nilai variabel kualitas produk, maka akan semakin meningkatkan keputusan pembelian. Sementara itu, hasil pengujian hipotesis menunjukkan bahwa terdapat pengaruh yang signifikan kualitas produk terhadap keputusan pembelian. Adapun besar pengaruh kualitas produk terhadap keputusan pembelian adalah $65,3 \%$.

Hasil penelitian ini sejalan dengan penelitian yang pernah dilakukan Mandasari, et al., (2015), yang menemukan adanya pengaruh positif dan signifikan kualitas produk terhadap keputusan pembelian. Dalam hal ini, The Executive sudah mampu memberikan kualitas yang baik untuk konsumennya, ditandai dengan bahan baku produknya yang bagus sehingga memberikan kenyamanan kepada konsumen ketika produknya digunakan. Ketika produk memiliki kualitas yang baik, maka konsumen akan merasa keinginan dan kebutuhannya terpenuhi.

\section{Pengaruh Foreign Branding, Harga, dan Kualitas Produk terhadap Keputusan Pembelian}

Sementara itu, hasil pengujian hipotesis menunjukkan terdapat pengaruh yang signifikan foreign branding, harga, dan kualitas produk terhadap keputusan pembelian. Berdasarkan pengujian hipotesis menggunakan uji F, disimpulkan bahwa foreign branding, 
harga, dan kualitas produk berpengaruh secara simultan terhadap keputusan pembelian The Executive. Hasil uji $\mathrm{R}^{2}$ menunjukkan nilai $\mathrm{R}$ sebesar 0,817 , artinya korelasi atau hubungan antara keputusan pembeliandengan ketiga variabel independen (foreign branding, harga, dan kualitas produk) adalah kuat dan positif. Kontribusi ketiga variabel dalam menjelaskan keputusan pembelian adalah sebesar $66,7 \%$, sedangkan sisanya sebesar 33,3\% dijelaskan oleh faktor lain yang tidak diteliti dalam penelitian ini.

Hasil penelitian ini sejalan dengan hasil penelitian yang dilakukan oleh Aichner, et al., (2016) yang menyatakan bahwa adanya faktor foreign branding dapat menarik konsumen untuk melakukan pembelian. Pradopo (2019) mengatakan bahwa produk dengan foreign branding dianggap memiliki kualitas yang lebih tinggi, sehingga semakin baik kualitas yang diberikan maka semakin baik penilaian terhadap suatu merek yang menggunakan foreign branding.

Kemudian tidak hanya foreign branding, seorang pemasar perlu menetapkan strategi harga yang baik sesuai dengan kualitas yang akan diterima oleh konsumen. Menurut Kussudarsyana (2016) harga seringkali digunakan sebagai penanda (sinyal) kualitas yang baik dari suatu produk. Sehingga dengan adanya penetapan harga yang baik sesuai dengan kualitas yang akan diterima konsumen, dapat memunculkan keputusan pembelian.

Keterkaitan terhadap kualitas produk tersebut sejalan dengan pernyataan Sanad (2018), bahwa jika perusahaan menjunjung tinggi kualitas produk, maka perusahaan akan mendapatkan jumlah konsumen yang diharapkan. Hal ini diperkuat pula dengan penelitian Andriani et al., (2019), yang menunjukkan bahwa semakin tinggi kualitas produk, maka semakin yakin konsumen untuk melakukan pengambilan keputusan pembelian. Sementara itu, dalam hal ini berarti semakin baik strategi foreign branding, harga, dan kualitas produk The Executive terhadap konsumen, maka akan meningkatkan keputusan pembelian.

\section{KESIMPULAN}

Secara teoritis, hasil ini mendukung teori dari Kotler \& Keller (2016:187), bahwa berdasarkan model perilaku konsumen, untuk mencapai keputusan pembelian, konsumen melewati tahapan proses keputusan pembelian yang dipengaruhi oleh stimulus pemasaran yaitu pada ketiga variabel penelitian ini (foreign branding, harga, dan keputusan pembelian). Pada penelitian ini pengaruh terbesar terletak pada variabel kualitas produk. Hal ini menjelaskan bahwa pada industri fashion, kualitas produk menjadi faktor utama yang mendukung keputusan pembelian.

Walaupun demikian, pada variabel keputusan pembelian, penilaian responden tertinggi, justru telah sampai pada tahap kepuasan yang dirasakan konsumen. Sehingga, hasil penelitian ini tidak dapat menangkap fenomena tersebut secara komprehensif. Perlu dilakukan pengembangan lebih lanjut pada penelitian yang akan datang, dengan menambahkan variabel kepuasan konsumen, karena hasil penelitian ini menunjukkan bahwa kepuasan menjadi penilaian tertinggi responden.

Secara praktis, hasil penelitian ini juga berimplikasi bagi produsen dan pemasar produk fashion, khususnya The Executive, dalam memahami penggunaan strategi foreign branding, keterkaitannya dengan harga, dan kualitas produk dalam mempengaruhi keputusan pembelian konsumen. Walaupun terdapat pengaruh foreign branding terhadap keputusan pembelian, tetapi kualitas produk tetap menjadi faktor yang dominan dalam 
mempengaruhi keputusan pembelian produk fashion, terutama pada aspek reliabilitas (keandalan) produk dalam memberikan kenyamanan.

\section{DAFTAR PUSTAKA}

Aichner, T., Forza, C., \& Trentin, A. (2016). The country of origin lie: Impact of foreign branding on customer's willingness to buy and willingness to pay when the product's actual originis disclosed. The International Review of Retail, Distribution and Consumer Research, 0959-3969.

Andriani, W., Abdurrahaman, \& Sari, P. R. K. (2019). Pengaruh kualitas produk, harga, dan promosi terhadap keputusan pembelian air mineral dalam kemasan merek Dharma (Studi kasus pada konsumen CV. Bahana Tirta Alam Maritim di Kab. Sumbawa Besar). Jurnal Manajemen dan Bisnis, 2, (1).

Asshiddieqi, F. \& Mudiantono. (2012). Analisis pengaruh harga, desain produk dan citra merek terhadap keputusan pembelian (Studi kasus pada produk Crooz di Distro Ultraa Store Semarang). Diponegoro Journal Of Management, 1(1).

Diantanti, N. P., Sunaryo, \& Rahayu, M. (2018). Perbandingan local name brand dan foreign name brand pada produk fashion di Kota Malang (Studi pada mahasiswa Universitas Brawijaya). Jurnal Bisnis dan Manajemen, 5(1).

Ergin, E. A., Akbay, H. O., \& Ozsacmaci, B. (2014). Insights into consumer preference of foreign brand names: Reality or myth? International Journal of Marketing Studies, 6(4).

Fatmawati, A., \& Suryoko, S. (2018). Pengaruh citra merek, kualitas produk, dan harga terhadap keputusan pembelian produk Charles \& Keith Paragon Semarang. Jurnal Ilmu Administrasi Bisnis, 7(1).

Ghozali, I. (2011). Aplikasi analisis multivariate dengan program SPSS. Semarang: Badan Penerbit Universitas Diponegoro.

Haris, A. (2018). Ivan Gunawan pastikan pakaian ready to wear makin melejit di 2019. Akurat.co. Akurat.co. Diakses dari [https://akurat.co/gayahidup/id-455633-read-ivan-gunawan-pastikan-pakaian-readyto-wear-makin-melejit-di-2019].

Kotler, P., \& Armstrong, G. (2016). Principles of marketing, 16th Edition. New Jersey: Pearson Education.

Kotler, P., \& Keller, K. L. (2016). Marketing management, 15th Edition. New Jersey: Pearson education.

Kussudyarsana. (2016). Persepsi konsumen atas merek lokal dan asing pada kategori produk hedonik dan utilitarian. Benefit Jurnal Managemen dan Bisnis, 1(1), 48-56.

Mandasari, G., Suharyono, \& Sunarti. (2015). Pengaruh citra merek internasional dan kualitas produk terhadap keputusan pembelian (Survey terhadap pembeli pakaian merek Zara di Galaxy Mall Surabaya). Jurnal Administrasi Bisnis (JAB), 24(1).

Margaretta, Y. (2017). Masyarakat Indonesia semakin sadar mode dan siap terjun ke industri fashion. Wartakota.tribunnews.com.

Diakses

dari [https://wartakota.tribunnews.com/2017/11/13/masyarakat-indonesia-semakin-sadar-mode-dansiap-terjun-ke-industri-fashion].

Pradopo, L. R. (2019). Pengaruh pemberian merek berbahasa asing dan citra merek CFC terhadap penjualan PT. Pioneerindo Gourmet Internasional, Tbk. Journal of Information System, Applied, Management, Accounting and Research, 3(2).

Priyatno, D. (2010). Teknik mudah dan cepat melakukan analisis data penelitian dengan SPSS. Yogyakarta: Gava Media.

Sanad, A. (2018). Analisis pengaruh harga, kualitas produk, citra merek, dan promosi terhadap minat beli local brand pada produk fashion (Studi pada mahasiswa fakultas ekonomi dan bisnis Universitas Muhammadiyah Surakarta). Skripsi. Fakultas Ekonomi dan Bisnis, Universitas Muhammadiyah Surakarta: Surakarta.

Sugiono, A., Arifianti, R., Raharja, S. J., \& Maulina, E. 2017. Dynamic Capabilities: Strategi dan Kunci Sukses Persaingan dalam Bidang Industri Kreatif. Penerbit Ombak, Yogjakarta. ISBN 9786022584551

Sugiyono. (2017). Metode penelitian kuantitatif, kualitatif, dan $R \mathcal{E}$ D. Bandung: Alfabeta.

Villar, M. E., Ai, D., \& Segev, S. (2012). Chinese and American perceptions of foreign-name brands. Journal of Product \& Brand Management, 341-349.

The Executive. (2020). Our store. The executive.co.id. Diakses dari [https://theexecutive.co.id/our-store].

Top Brand Award. (2020). Top Brand Index Fase 2 2020. www.topbrand-award.com. Diakses dari [https://www.topbrand-award.com/top-brand-index/]. 